\title{
The estimation of magnesium in small biological samples by flame spectrophotometry
}

\author{
R. D. MONTGOMERY \\ From the Medical Research Council Tropical Metabolism Research Unit, University \\ College of the West Indies, Jamaica
}

SYNOPSIS Studies of human magnesium metabolism in this laboratory called for a simple and reliable method of estimating the magnesium content of large numbers of small biological specimens (Montgomery, 1960). It has been found that a technique involving the Unicam S.P. 900 flame ${ }_{0}$ spectrophotometer fulfils this need.

Estimations have been made on serum, red cells, urine, and acid digests of muscle and faeces. $\stackrel{\bigcirc}{=}$ A standard instrument was used, burning acetylene and air, with a new standard atomiser containing a metal jet. Readings were made at the atomic line of $285.2 \mathrm{~m} \mu$.

\section{FLAME CHARACTERISTICS}

The difficulties and complications involved in studying the magnesium emission, and the disadvantages of using the oxide line at $371 \mathrm{~m} \mu$, have been discussed by Teloh (1958) and by Van Fossan, Baird, and Tekell (1959). In general, magnesium is liable to interference by sodium and potassium and to a lesser extent by calcium and phosphate in biological fluids. Practical problems are presented by the high concentration of sodium in serum and of potassium in intracellular fluid. At the magnesium atomic line, part of the sodium effect is due to the presence of a sodium line at $285.3 \mathrm{~m} \mu$, which should be readily corrected by the use of a sodium blank. There is also, however, a more general effect of mutual interference by extraneous cations; from analysis with a multichannel instrument, Margoshes and Vallee (1956) concluded that this is due to variation of heterochromatic background radiation in the presence of the specific flame, and not to intrinsic alteration of its monochromatic emission.

In the S.P. 900 instrument, spraying $1: 10$ dilutions of serum and 1:50 extracts of tissue, these effects can be corrected by the use of blanks and standards with the appropriate electrolyte concentrations. The background interference curves of both sodium and potassium in increasing concentrations with constant magnesium were found to approach the horizontal at concentrations above $10 \mathrm{mEq}$. per litre of sodium and $1 \mathrm{mEq}$. per litre of potassium.

Received for publication 20 April 1961.
In other words, using the appropriate 'normal' blanks, no significant variation was found in theo readings of a magnesium solution of $0.2 \mathrm{mEq}$. per litre $(2.45$ p.p.m.) in the presence of sodium and potassium in concentrations equivalent to the $\frac{\mathcal{Q}}{\mathbb{Q}}$ extreme ranges which may be found either in $1: 10$ 을 serum or $1: 50$ muscle extracts.

These interference effects, being non-linear, are relatively enhanced the higher the dilutions used, which in the above instances approach the working: limit of the instrument. In $1: 10$ serum the overalio effect of sodium was approximately $12 \%$ of the magnesium reading. In undiluted urine and in faecal 3 . extracts, on the other hand, both because the con- $\dot{\delta}$ centrations are higher and because the proportion 3 of sodium to magnesium tends to be lower, thiso type of interference is found to be insignificant.

The calibration curve of magnesium in these higher concentrations is shown in Fig. 1. This was obtained with a slit width of $0.08 \mathrm{~mm}$. and a gain? setting of $4 \cdot 3$. The shape of the curve is determined 0 by a self-absorption phenomenon with increasing ${ }_{\mathcal{E}}^{N}$ concentration.

In the estimation of magnesium traces, it is inevitable that the total background will be relatively high. The following figures obtained at very low sensitivity (slit $0.1 \mathrm{~mm}$., gain 3.6 ) show that the magnesium in $1 / 10$ serum contributes some $8 \%$ of the total light at $285.2 \mathrm{~m} \mu$.

Galvanometer reading with flame off $\ldots \ldots \ldots \ldots \ldots \ldots \ldots \ldots$

Galvanometer reading with deionized water............64

Galvanometer reading with $1 / 10$ serum blank.............64

Galvanometer reading with blank + Mg. $0.2 \mathrm{mEq}$. per litre...69.5 


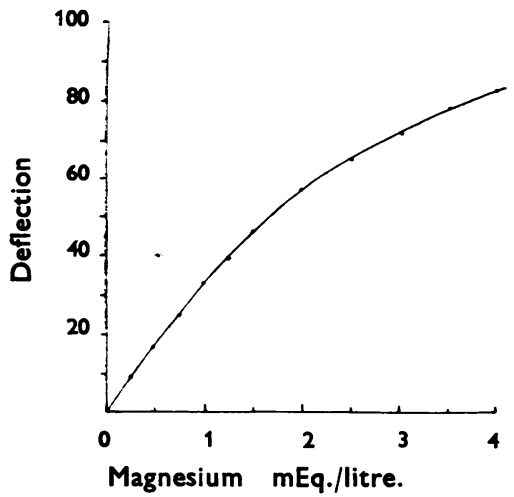

FIG. 1. Magnesium standard curve, 0-4 mEq. per litre.

The accuracy and reproducibility of the estimation therefore depends to a large extent on the stability of background. The degree of this stability can be deduced from the figures in Table I.

TABLE I

RECOVERY OF ADDED MAGNESIUM IN SERUM

\begin{tabular}{|c|c|c|c|}
\hline Sample & $\begin{array}{l}\text { Added Mg. } \\
\text { (mEq. per } \\
\text { litre) }\end{array}$ & Deflection & $\begin{array}{l}\text { Recovery } \\
\text { (mEq.per } \\
\text { litre) }\end{array}$ \\
\hline Blank & - & 0 & - \\
\hline $\begin{array}{l}\text { Standard } \\
0.1 \mathrm{mEq} . \text { per litre } \\
" \\
"\end{array}$ & $\begin{array}{l}\overline{-} \\
0 \cdot 150 \\
0 \cdot 300\end{array}$ & $\begin{array}{r}26 \\
62 \\
100\end{array}$ & $\begin{array}{l}0 \cdot 140(93 \%) \\
0 \cdot 288(99 \%)\end{array}$ \\
\hline $\begin{array}{l}\text { Standard } \\
0.16 \text { mEq. per litre } \\
\text { ", }\end{array}$ & $\overline{0.150}$ & $\begin{array}{l}41 \\
78\end{array}$ & $0.1 \overline{44}(96 \%)$ \\
\hline Blank & - & 0 & - \\
\hline $\begin{array}{c}\text { Serum A }(1: 10) \\
",\end{array}$ & $\overline{0 \cdot 150}$ & $\begin{array}{l}40 \\
75\end{array}$ & $0 \cdot 13 \overline{6}(91 \%)$ \\
\hline $\begin{array}{c}\text { Serum B }(1: 10) \\
"\end{array}$ & $\overline{0.150}$ & $\begin{array}{l}46 \\
83\end{array}$ & $0.1 \overline{4}(96 \%)$ \\
\hline $\begin{array}{c}\text { Serum C }(1: 10) \\
"\end{array}$ & $\begin{array}{l}\overline{0 \cdot 150} \\
\text { TECHNIQ }\end{array}$ & $\begin{array}{l}49 \\
87\end{array}$ & $0 \cdot \overline{48}(99 \%)$ \\
\hline
\end{tabular}

SERUM A stock serum blank solution is prepared by adding to 1 litre of deionized water sodium $140 \mathrm{mEq}$. ( $\mathrm{NaCl} 8.19 \mathrm{~g}$. ), potassium $4 \mathrm{mEq}$. (K Cl $298 \mathrm{mg}$.), and calcium $5 \mathrm{mEq}$. $\left(\mathrm{CaCO}_{3} 250 \mathrm{mg}\right.$. dissolved in $\left.\mathrm{HCl}\right)$. This solution is diluted $1: 10$ for use.

Standards are prepared by adding weighed amounts of magnesium sulphate to the undiluted blank to give a range from 0.5 to $4 \mathrm{mEq}$. per litre. This is diluted $1: 10$.

A minimum of $200 \mu \mathrm{l}$. serum is freshly diluted to $1: 10$ in deionized water and assayed at the magnesium atomic line of $285.2 \mathrm{~m} \mu$, using a slit width of $0.1 \mathrm{~mm}$. and a gain setting of about $5 \cdot 8$ (Fig. 2).

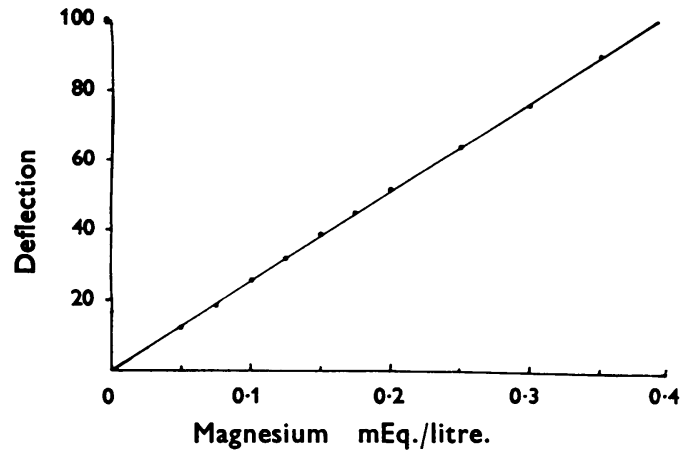

FIG. 2. Magnesium standard curve, 0-0.4 mEq. per litre used for estimations in $1: 10$ serum.

Good recovery is obtained of added magnesium (Table I). Fig. 3 is a frequency histogram of normal sera assayed as described. This is at some variance with that of Wacker and Vallee (1957), but agrees with findings of

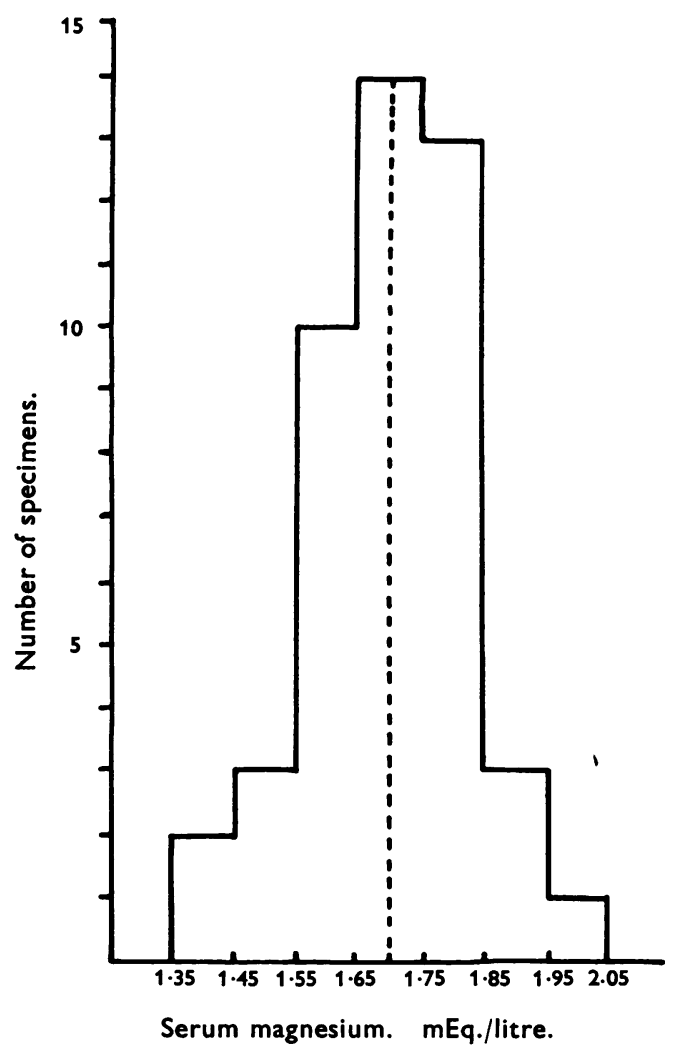

FIG. 3. Frequency histogram of serum magnesium content of 46 normal sera from West Indian adults. 
MacIntyre and Davidsson (1958) and Van Fossan et al. (1959), using different instruments and techniques. The standard curve (Fig. 2) is more sensitive than that of Van Fossan et al., who used an oxyhydrogen flame in a modified Beckman instrument.

MUSCLE AND RED CELLS Nitric acid digests of muscle in $1: 50$ dilution and red cell preparations lysed in a dilution of $1: 25$ may be estimated at approximately the same slit widths and gain settings as above. Magnesium estimations can thus be made in addition to other assays on muscle biopsy specimens of 50 to $150 \mathrm{mg}$. wet weight.

Nitric acid causes interference with the flame which becomes significant at concentrations around $0 \cdot 1 \mathrm{~N}$, and cannot be fully compensated by blank. The muscle should therefore be wet-ashed and partially homogenized in $0.2 \mathrm{~N}$ acid and diluted to a final concentration of $0.04 \mathrm{~N}$.

The stock blank contains per litre K $15 \mathrm{mEq}$., Na 15 mEq., and $\mathrm{PO}_{4} 10$ m.M., made by dissolving $1.065 \mathrm{~g}$. $\mathrm{K}_{3} \mathrm{PO}_{4}$ and $1.725 \mathrm{~g}$. $\mathrm{Na}_{3} \mathrm{PO}_{4} \cdot 10 \mathrm{H}_{2} \mathrm{O}$ in 1 litre, and is diluted 1:10 for use. Standards are prepared in the undiluted blank as for serum and are then diluted $1: 10$. The diluted blank represents a $1: 50$ dilution of the approximate electrolyte concentrations in the tissues (K $75 \mathrm{mEq}$., $\mathrm{Na} 75 \mathrm{mEq}$., and phosphate $50 \mathrm{~m} . \mathrm{M}$. per litre), and in practice permits accuracy over the full range of normal and abnormal tissue concentrations.

URINE Undiluted acidified urine may be assayed directly against deionized water. The standard curve in Fig. 1 is appropriate. In cases of magnesium deficiency, urinary $\stackrel{\stackrel{2}{\overrightarrow{0}}}{\overrightarrow{0}}$

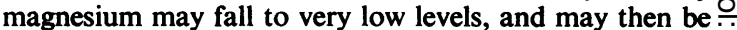
assayed against the standards for $1: 10$ serum using the $\overrightarrow{\vec{F}}$ serum blank.

FAECES Aliquots of faecal collections are evaporated $\frac{\bar{\sigma}}{\sigma}$ overnight at $110^{\circ} \mathrm{C}$., and are then treated with $6 \mathrm{~N}$ nitric $\frac{\bar{\rho}}{\partial}$ acid in a boiling water bath. The digest is diluted, separated $\mathbb{D}$ from fat, and centrifuged if necessary. The final acid concentration should not exceed $0.5 \mathrm{~N}$ and the appropriate $\omega$ amount of nitric acid must be added to standards and $\vec{\circ}$ blank.

\section{PRECAUTIONS}

Care is required in maintaining the acetylene flow: constant as it may be liable to minute but highly significant fluctuations. Another source of error in testing biological fluids is partial blockage of the atomiser. Both must be averted by frequent reference to the standards and blank. The modified atomiser enables clearance to be made by a stilette without interruptiou of the flame.

\section{REFERENCES}

MacIntyre, I., and Davidsson, D. (1958). Biochem. J., 70, 456. Margoshes, M., and Vallee, B. L. (1956). Anal. Chem., 28, 1066. Montgomery, R. D. (1960). Lancet, 2, 74.

Teloh, H. A. (1958). Amer. J. clin. Path., 30, 129.

Van Fossan, D. D., Baird, E. E., and Tekell, G. S. (1959). Ibid, 31, 368.

Wacker, W. E. C., and Vallee, B. L. (1957). New Engl. J. Med., 257, 1254. 